\title{
Deep Brain Stimulation for the Treatment of Juvenile Parkinsonism: Case Report
}

\section{Estimulação cerebral profunda no tratamento do parkinsonismo juvenil: relato de caso}

\author{
Oliveiros de Oliveira e Silva Neto ${ }^{1}$ Adailson Soares de Sousa ${ }^{1}$ Ledismar José da Silva ${ }^{1 \odot}$ \\ 1 School of Medical, Pharmaceutical, and Biomedical Sciences, \\ Pontifícia Universidade Católica de Goiás, Goiânia, GO, Brazil \\ Arq Bras Neurocir 2019;38:124-127. \\ Address for correspondence Ledismar José da Silva, MSc, School of \\ Medicine, Pontifícia Universidade Católica de Goiás (PUC-Goiás), \\ Avenida Universitária, 1440, Setor Universitário, Goiânia, GO \\ 74605-010, Brazil (e-mail: ledismarsilva@gmail.com).
}

\begin{abstract}
Keywords

- juvenile parkisonism

- deep brain stimulation

- subthalamic nucleus

- neurosurgery

- dysarthria
\end{abstract}

\section{Resumo}

\section{Palavras-chave}

- parkinsonismo juvenil

- estimulação cerebral profunda

- núcleo subtalâmico

- neurocirurgia

- disartria
Juvenile parkinsonism (JP) is characterized by the clinical manifestation of Parkinson syndrome before the age of 21 years old. This entity is often associated with genetic mutations. After all the possibilities of clinical treatment have been exhausted, surgical treatment is recommended, performed via deep brain stimulation (DBS) in the subthalamic nucleus (STN) or in the internal segment of the globus pallidus (GPi). The present study aimed to report the case of a patient with JP who underwent DBS in the STN with good clinical response. Neuromodulation via DBS is an option for the treatment of JP. However, since this entity is very rare, and even more peculiar when treated surgically, more studies are necessary to evaluate DBS used to control refractory manifestations and levodopa-induced dyskinesia, as well as surgical complications that may occur, aiming to gather more knowledge of the surgical management of JP. Despite the dysarthria after the DBS, the patient presented a satisfactory response regarding the symptoms, corroborated by the Parkinson's Disease Questionnaire (PDQ-39) score, which was $61.19 \%$ before the procedure, and decreased to $21.05 \% 14$ months after the DBS.

O parkinsonismo juvenil (PJ) é caracterizado pela manifestação clínica da síndrome de Parkinson antes dos 21 anos de idade. Esta entidade está frequentemente associada a mutações genéticas. Depois de esgotadas todas as possibilidades de tratamento clínico, institui-se o tratamento cirúrgico, que é realizado via estimulação cerebral profunda (ECP) no núcleo subtalâmico (NST) ou no globo pálido interno (GPi). O presente trabalho teve como objetivo relatar o caso de um paciente com PJ que foi submetido à ECP no NST com boa resposta clínica. A neuromodulação via ECP apresenta-se como uma opção de tratamento para o PJ. Contudo, em decorrência da raridade desta entidade, que se torna ainda mais peculiar quando abordada cirurgicamente, são necessários mais estudos que avaliem a ECP utilizada para controlar as manifestações refratárias e a discinesia induzida por levodopa, assim

(DLedismar José da Silva's ORCID is 0000-0002-3551-2650.

received

June 20, 2018

accepted

February 19, 2019
DOI https://doi.org/

10.1055/s-0039-1685151. ISSN 0103-5355.
Copyright (e 2019 by Thieme Revinter

Publicações Ltda, Rio de Janeiro, Brazil
License terms

(c) $(1) \$$ 
como as complicações cirúrgicas que podem ocorrer, com o intuito de propiciar maior conhecimento sobre o manejo cirúrgico do PJ. Apesar da disartria apresentada após a ECP, o paciente teve resposta satisfatória em relação aos sintomas, o que foi corroborado pela pontuação na escala Parkinson's Disease Questionnaire (PDQ-39), que era $61,19 \%$ antes do procedimento e, 14 meses após a ECP, diminuiu para $21,05 \%$.

\section{Introduction}

Parkinson disease (PD) is a syndrome characterized by at least two of the following symptoms: bradykinesia, rigidity, tremor, and postural changes. ${ }^{1-3}$ Idiopathic Parkinson disease is the idiopathic form of this condition, corresponding to between 75 and $80 \%$ of the cases. ${ }^{4}$ The incidence of PD increases with age, and this syndrome is not common in individuals $<50$ years old. ${ }^{4,5}$ In cases the aforementioned clinical manifestations develop between the ages of 21 and 40 years old, the syndrome is called early-onset PD (EOPD), ${ }^{4,6,7}$ whereas in cases they appear before the age of 21 years old, it is called juvenile parkinsonism (JP).,6-8

Juvenile parkinsonism is a rare condition that is more commonly reported in association with a family history of PD. ${ }^{4,7}$ Many patients may have atypical manifestations. Although some cases are typically idiopathic, secondary causes prevail. Therefore, the idiopathic origin is a very rarely described cause. ${ }^{7,8}$

In PD, surgical treatment is an option after the control of symptoms with medication has failed and levodopa-related complications have appeared. Currently, deep brain stimulation (DBS) of different surgical targets is the treatment employed for PD. The present study aimed to report the case of a patient who underwent a surgical treatment using DBS to control JP.

\section{Case Report}

A male patient presented with micrographia at 14 years old and asymmetric resting tremor of upper limb extremities at 19 years old, predominantly on the left side, associated with rigidity and bradykinesia, but he did not have any nonmotor symptoms associated to PD. At 21 years old, he was diagnosed with JP in its primary form, after other secondary and family forms were not confirmed. The patient had no family history of any neurological diseases.

The patient showed a good response to levodopa until he was 30 years old. However, in the following 10 years, he experienced progressive levodopa-induced dyskinesia and an increased frequency of on/off periods, which significantly compromised his quality of life, in spite of the optimized clinical treatment, with $1600 \mathrm{mg} /$ day of levodopa, $4 \mathrm{mg} /$ day of pramipexole, and $400 \mathrm{mg} /$ day of amantadine.

At 40 years old, that is, 19 years after the patient was diagnosed with JP, he underwent DBS with electrodes placed bilaterally in the subthalamic nucleus (STN). Before the surgery, his quality of life was measured using the Parkinson's Disease Questionnaire (PDQ-39), and his score was 61.19\%.
Three months after the surgery, the patient presented with dysarthria, which persists until now. Nevertheless, he showed significant improvements on dyskinesia and on/off motor fluctuations, leading to a decrease in the doses of the medications. After the procedure, the clinical treatment was changed, and the patient now takes $600 \mathrm{mg} /$ day of levodopa, $3 \mathrm{mg} /$ day of pramipexole, and $300 \mathrm{mg} /$ day of amantadine. Furthermore, 14 months after the DBS, a global improvement was confirmed based on a decrease of his PDQ-39 score to $21.05 \%$.

\section{Discussion}

Juvenile parkinsonism is an entity described as clinically and pathologically distinct from EOPD, ${ }^{4,7}$ not only because of the age groups they affect. Different from PD and EOPD, the histopathological finding of Lewy bodies is rare in JP., ${ }^{4,7}$ This is the reason the term JP is adopted in these cases instead of juvenile PD, in spite of the similar clinical manifestations. ${ }^{6}$

In cases of JP, both the association of the disease with genetic mutations and the presence of a family history are well described. ${ }^{4,6}$ It is known that mutations in the parkin gene are among the most common causes of JP. ${ }^{6,7,9,10}$ In some studies, alterations in the PARK2 gene, related to the chromosome 6q25-27, were found to be responsible for autosomal recessive JP in $50 \%$ of the family cases analyzed, ${ }^{10,11}$ as well as in between 15 and $77 \%$ of the sporadic cases in patients $\leq 21$ years old. ${ }^{11,12}$ The PARK2 gene is related to the parkin protein, an enzyme associated with the removal of damaged mitochondria, which also promotes the degradation of $\alpha$-synuclein. ${ }^{7,9,10}$ Two other mutations correlated with JP are found in the chromosome 1p in the PARK6 and PARK7 genes, although they may also be involved in other clinical entities in patients $>40$ years old.

The patient of the present case report had no family history of motor dysfunction and did not present with atypical manifestations that could suggest other forms of parkinsonism. These findings indicate a sporadic case of JP. The clinical manifestations that corroborate the similarity of the evolution of his condition to that of PD were the presence of bradykinesia, rigidity, and resting tremor, the prospective findings of asymmetry of these manifestations, the progressive nature of the disease, and its good response to levodopa, in association with the exclusion of other diseases. These findings fulfill the clinical diagnostic criteria of PD described in the literature. ${ }^{13,14}$ The regular clinical treatment of PD can also be used to treat patients with $\mathrm{JP}^{4,7}$ and it was chosen for the patient of the present case report. Nonetheless, the 
patient presented with levodopa-induced motor fluctuations and dyskinesia in less than 5 years. In cases of parkinsonism with onset at ages $<40$ years old, early motor complications such as on/off periods and severe dyskinesia are observed. ${ }^{15,16}$

In treatment-refractory cases, DBS treatment is the surgical option for patients with PD. ${ }^{17}$ The STN, the internal globus pallidus (GPi), and the ventral intermediate thalamic nucleus (VIM) are described as surgical targets in DBS. ${ }^{17,18}$ The STN and the GPi have more clinical applications and, comparatively, no differences were found between their efficacy. ${ }^{19,20}$ Deep brain stimulation treatment targeting the VIM has been proven to control tremors; however, since it has been considered insufficient to control other motor symptoms, it is not indicated for the treatment of PD. ${ }^{18,19}$

The depletion of dopamine in the nigrostriatal pathway leads to a decrease in the inhibitory activity of striatum units along the indirect pathway, resulting in the inhibition of the external globus pallidus (GPe) and in the consequent disinhibition of the STN, which in association with a decrease in the excitatory influence on striatal units along the direct pathway, strongly disinhibits the $\mathrm{GPi},{ }^{21,22}$ having as a final consequence a lower thalamocortical activity. ${ }^{22}$ In patients with JP, DBS still needs more systematic studies. In advanced PD, STN hyperactivity is a landmark for neurophysiological mapping. Nonetheless, so far, no studies have detailed whether the same happens in cases of early onset PD. ${ }^{23}$

In the present case, the surgical target was the STN, which can be divided into three parts: dorsolateral, ventromedial, and medial. ${ }^{24}$ The dorsolateral portion houses the sensorimotor region, and its precise location is of great importance to achieve the best clinical response regarding the motor symptoms of $\mathrm{PD}$ patients and to reduce the adverse effects on cognition and behavior. ${ }^{25}$ In the treated patient, several landmarks ${ }^{26}$ were used in an integrated way via magnetic resonance imaging (MRI) to locate the dorsolateral portion of the STN and to optimize the implantation of the electrodes.

Although the patient of the present case report presented with early clinical manifestations, he underwent DBS only 20 years after the diagnosis, already in an advanced phase of the disease and with serious motor complications. In the few cases of JP reported in the literature, the eligibility for DBS has been greatly based on the phenotype of the patients and on their responsiveness to levodopa. ${ }^{27-29}$ For instance, the treatment of a 14-year-old patient, with several motor fluctuations, using bilateral DBS in the STN, has been described. Satisfactory results were obtained with this treatment for JP, even though he became refractory to levodopa and had complications in less than 5 years. ${ }^{27}$ In another case, a 26-year-old JP patient, with onset estimated 8 years before, underwent DBS having GPi as a target. The outcome was satisfactory, since the symptoms were controlled. ${ }^{28}$ Advanced PD patients, with disease onset 40 years before, have benefited from DBS in the STN, with a decrease in dyskinesia and motor fluctuations. ${ }^{29,30}$

In spite of the paucity of controlled trials, in some studies it has been reported that DBS can be a good option for the treatment of JP, because it permits the decrease in the dosage of the medication and improves dyskinesia and on/off periods, as observed in the patient of the present case report.

Aiming to measure the perception of the patient of his quality of life before and after the surgical procedure, the PDQ-39 was employed. It is a self-report questionnaire, composed of 39 items, which encompasses 8 daily life dimensions (mobility: items 1-10; activities of daily living (ADL): items 11-16; emotional well-being: items 17-22; stigma: items 23-26; social support: items 27-29; cognition: items 30-33; communication: items 34-36; bodily discomfort: items 37-39), intended to measure the quality of life of PD patients during the last month, using a 5-point Likert scale (never $=0$; occasionally $=1$; sometimes $=2$; often $=3$; always $=4)^{31}{ }^{31}$ The highest scores are correlated with a worse quality of life.

Before the surgical procedure, the global percentage of the patient was $61.19 \%$ and, 14 months after the DBS, it decreased to $21.05 \%$. These results, comparable to literature data, $^{32-34}$ showed a significant decrease in the score, pointing to an improvement in his quality of life. However, the oral communication of this patient was impaired after the DBS, due to dysarthria that occurred as a complication of the procedure. Before the surgery, it was $3.4 \%$ of the total score, whereas, 14 months after the DBS, it was $44.5 \%$. In another study, after DBS treatment for PD, $12.8 \%$ of the patients had oral communication impairment. ${ }^{35}$ Due to the rarity of JP cases, no cases of patients that underwent DBS and had dysarthria, similarly to the case presented here, were found. Further studies should be conducted to follow the long-term repercussions and the efficacy of DBS in JP patients.

\section{Conclusion}

Few cases of DBS in JP patients have been reported. The patient of the present case report had a good response to DBS with the electrodes placed bilaterally in the STN, with a global improvement in his quality of life, even with dysarthria as a surgical complication. The present study evidences that DBS in the STN is an option for treating JP.

Conflicts of Interests

The authors have no conflicts of interests to declare.

\section{References}

1 Williams DR, Litvan I. Parkinsonian syndromes. Continuum (Minneap Minn) 2013;19(5 Movement Disorders):1189-1212

2 Guimarães J, Alegria P. O parkinsonismo. Med Int 2004;11(02): 109-114

3 Weiner WJ. A differential diagnosis of Parkinsonism. Rev Neurol Dis 2005;2(03):124-131

4 Uc EY, Rodnitzky RL. Juvenile parkinsonism. Semin Pediatr Neurol 2003;10(01):62-67

5 de Lau LM, Breteler MM. Epidemiology of Parkinson's disease. Lancet Neurol 2006;5(06):525-535

6 Paviour DC, Surtees RA, Lees AJ. Diagnostic considerations in juvenile parkinsonism. Mov Disord 2004;19(02):123-135

7 Thomsen TR, Rodnitzky RL. Juvenile parkinsonism: epidemiology, diagnosis and treatment. CNS Drugs 2010;24(06):467-477 
8 Cardoso F, Camargos S. Juvenile parkinsonism: a heterogeneous entity. Eur J Neurol 2000;7(05):467-471

9 Delamarre A, Meissner WG. Epidemiology, environmental risk factors and genetics of Parkinson's disease. Presse Med 2017;46(2 Pt 1):175-181

10 Kalia LV, Lang AE. Parkinson's disease. Lancet 2015;386(9996): 896-912

11 Lücking CB, Dürr A, Bonifati V, et al; French Parkinson's Disease Genetics Study Group; European Consortium on Genetic Susceptibility in Parkinson's Disease. Association between early-onset Parkinson's disease and mutations in the parkin gene. N Engl J Med 2000;342(21):1560-1567

12 Periquet M, Latouche M, Lohmann E, et al; French Parkinson's Disease Genetics Study Group; European Consortium on Genetic Susceptibility in Parkinson's Disease. Parkin mutations are frequent in patients with isolated early-onset parkinsonism. Brain 2003;126(Pt 6):1271-1278

13 Hughes AJ, Daniel SE, Kilford L, Lees AJ. Accuracy of clinical diagnosis of idiopathic Parkinson's disease: a clinico-pathological study of 100 cases. J Neurol Neurosurg Psychiatry 1992;55(03): 181-184

14 Bhidayasiri R, Reichmann H. Different diagnostic criteria for Parkinson disease: what are the pitfalls? J Neural Transm (Vienna) 2013;120(04):619-625

15 Schrag A, Schott JM. Epidemiological, clinical, and genetic characteristics of early-onset parkinsonism. Lancet Neurol 2006;5 (04):355-363

16 Schapira AH. Treatment options in the modern management of Parkinson disease. Arch Neurol 2007;64(08):1083-1088

17 Munhoz RP, Picillo M, Fox SH, et al. Eligibility criteria for deep brain stimulation in Parkinson's disease, tremor, and dystonia. Can J Neurol Sci 2016;43(04):462-471

18 Wagle Shukla A, Okun MS. Surgical treatment of Parkinson's disease: patients, targets, devices, and approaches. Neurotherapeutics 2014;11(01):47-59

19 Honey CR, Hamani C, Kalia SK, et al. Deep brain stimulation target selection for Parkinson's disease. Can J Neurol Sci 2017;44(01):3-8

20 Follett KA, Weaver FM, Stern M, et al; CSP 468 Study Group. Pallidal versus subthalamic deep-brain stimulation for Parkinson's disease. N Engl J Med 2010;362(22):2077-2091

21 Wichmann T, DeLong MR. Pathophysiology of Parkinson's disease: the MPTP primate model of the human disorder. Ann N Y Acad Sci 2003;991(01):199-213

22 DeLong MR, Wichmann T. Circuits and circuit disorders of the basal ganglia. Arch Neurol 2007;64(01):20-24
23 Gill CE, Allen LA, Konrad PE, et al. Deep brain stimulation for earlystage Parkinson's disease: an illustrative case. Neuromodulation 2011;14(06):515-521, discussion 521-522

24 Massey LA, Yousry TA. Anatomy of the substantia nigra and subthalamic nucleus on MR imaging. Neuroimaging Clin N Am 2010;20(01):7-27

25 Brunenberg EJ, Platel B, Hofman PA, Ter Haar Romeny BM, VisserVandewalle V. Magnetic resonance imaging techniques for visualization of the subthalamic nucleus. J Neurosurg 2011;115(05): 971-984

26 Normanha LL Leão JRB, Silva LJ. Landmarks para a localização do núcleo subtalâmico por ressonância magnética. Arq Bras Neurocir 31 May 2017 (eFirst)

27 Genç G, Apaydın H, Gündüz A, et al. Successful treatment of Juvenile parkinsonism with bilateral subthalamic deep brain stimulation in a 14-year-old patient with parkin gene mutation. Parkinsonism Relat Disord 2016;24:137-138

28 Perandones C, Aráoz Olivos N, Raina GB, et al. Successful GPi stimulation in genetic Parkinson's disease caused by mosaicism of alpha-synuclein gene duplication: first description. J Neurol 2015;262(01):222-223

29 Nakahara K, Ueda M, Yamada K, et al. Juvenile-onset parkinsonism with digenic parkin and PINK1 mutations treated with subthalamic nucleus stimulation at 45 years after disease onset. J Neurol Sci 2014;345(1-2):276-277

30 Lefaucheur R, Derrey S, Guyant-Maréchal L, Chastan N, Maltête D. Whatever the disease duration, stimulation of the subthalamic nucleus improves Parkin disease. Parkinsonism Relat Disord 2010;16(07):482-483

31 Martinez-Martin P, Jeukens-Visser M, Lyons KE, et al. Healthrelated quality-of-life scales in Parkinson's disease: critique and recommendations. Mov Disord 2011;26(13):2371-2380

32 Umemura A, Oyama G, Shimo Y, et al. Current topics in deep brain stimulation for Parkinson disease. Neurol Med Chir (Tokyo) 2016; 56(10):613-625

33 Baláž M, Bočková M, Rektor I. DBS amplitude setting can improve aspects of quality of life in patients with Parkinson's disease. J Neural Transm (Vienna) 2013;120(04):643-648

34 Sobstyl M, Ząbek M, Górecki W, Mossakowski Z. Quality of life in advanced Parkinson's disease after bilateral subthalamic stimulation: 2 years follow-up study. Clin Neurol Neurosurg 2014; 124:161-165

35 Videnovic A, Metman LV. Deep brain stimulation for Parkinson's disease: prevalence of adverse events and need for standardized reporting. Mov Disord 2008;23(03):343-349 